\title{
STUDI PERUBAHAN TUTUPAN LAHAN MANGROVE BERBASIS OBJEK (OBIA) MENGGUNAKAN CITRA SATELIT DI PULAU DOMPAK PROVINSI KEPULAUAN RIAU
}

\section{STUDY OF MANGROVE COVERAGE CHANGE BASED ON OBJECT (OBIA) USING SATELLITE IMAGERY IN DOMPAK ISLAND PROVINCE OF KEPULAUAN RIAU}

\author{
Robin Saputra ${ }^{1 *}$, Jonson L. Gaol ${ }^{2}$, \& Syamsul B. Agus ${ }^{2}$ \\ ${ }^{1}$ Program Studi Teknologi Kelautan, Sekolah Pascasarjana, IPB University, Bogor 16680, Indonesia \\ ${ }^{2}$ Departemen Ilmu dan Teknologi Kelautan, Fakultas Perikanan dan Ilmu Kelautan, \\ IPB University, Bogor, 16680, Indonesia \\ *E-mail: robinsaputra55@yahoo.co.id
}

\begin{abstract}
The threats on mangrove forest, either naturally such as climate change or human activities such as landfill, land-use change, and deforestation, can increase the vulnerability of this ecosystem itself. Remote sensing is an effective method to use as mangrove monitoring activity because it can be done periodically and can reach a large area. This research aims to analyse mangrove coverage changes in Dompak Island, Kepulauan Riau Province. The method that was used is satellite imagery classification based on object (OBIA) with support vector machine (SVM) algorithm. Satellite imagery data that was used are SPOT 4 in 2007 and Sentinel $2 B$ in 2018 with spatial resolution of $10 \times 10 \mathrm{~m}$. Ground check was conducted on September-October 2018 using random sampling method. The classification results of OBIA with SVM algorithm showed $89 \%$ accuracy level, 0.86 kappa values with optimum segmentation value of 3. Based on coverage land analysis, there was degradation of $34.19 \%$ mangrove area, or about $46.61 \mathrm{ha}$, since 2007 to 2018.
\end{abstract}

Keywords: classification, Dompak Island, mangrove, OBIA, sentinel 2B, SPOT 4

\begin{abstract}
ABSTRAK
Berbagai ancaman pada hutan mangrove baik secara alamiah seperti perubahan iklim dan kegiatan manusia seperti penimbunan, alih fungsi lahan dan penebangan semakin meningkatkan kerentanan ekosistem itu sendiri. Pengindraan jauh merupakan metode yang sangat efektif untuk digunakan dalam kegiatan pemantauan mangrove karena dapat dilakukan secara berkala dan mampu menjangkau area yang luas. Penelitian ini bertujuan untuk menganalisis perubahan tutupan mangrove di Pulau Dompak Provinsi Kepulauan Riau. Metode yang digunakan berupa klasifikasi citra satelit berbasis objek (OBIA) dengan algoritma support vector machine (SVM). Data citra satelit yang digunakan adalah SPOT 4 Tahun 2007 dan Sentinel 2B Tahun 2018 dengan resolusi spasial 10 x 10 m. Survei lapang dilakukan pada bulan September-Oktober 2018 dengan metode sampling secara acak. Hasil klasifikasi OBIA dengan algoritma SVM menghasilkan tingkat akurasi sebesar 89\%, nilai kappa 0,86 dengan skala segmentasi optimum yang diperoleh adalah skala 3. Berdasarkan analisis perubahan tutupan lahan terjadi adanya penurunan luasan hutan mangrove sebesar 34,19\% atau sekitar 46,61 ha sejak Tahun 2007 hingga 2018.
\end{abstract}

Kata kunci: klasifikasi, mangrove, OBIA, Pulau Dompak, sentinel 2B, SPOT 4

\section{PENDAHULUAN}

Hutan mangrove merupakan ekosistem pesisir yang dapat hidup di daerah tropis maupun sub-tropis di antara darat dan laut (Barati et al., 2011). Hutan mangrove sebagai ekosistem pesisir berfungsi sebagai pelindung pesisir dan pantai dari gangguan dan ancaman bencana alam seperti badai, tsunami, angin dan gelombang. Hutan 
mangrove juga berperan sebagai tempat pemijahan dan sumber nutrisi bagi ikan dan organisme lainnya (Mazda et al., 2002; Thampanya et al., 2006; Ostling et al., 2009; Carrasquilla-henao et al., 2013; Cannicci et al., 2008; Nagelkerken et al., 2008), hutan mangrove juga dijadikan sebagai tempat rekreasi atau wisata (Ahmad, 2009; Datta et al., 2012), tempat belajar atau pendidikan (Sarkar \& Bhattacharya, 2003) dan juga adanya fenomena perubahan iklim, mangrove berfungsi sebagai penyerap karbon (Gilman et al., 2006; Donato et al., 2011). Hutan mangrove walaupun banyak manfaat dan fungsinya, tapi juga rentan dan sensitif terhadap ancaman dan gangguan baik secara alamiah seperti perubahan iklim dan kegiatan manusia yang mengakibatkan degradasi seperti budi daya dan penebangan untuk dijadikan bahan kayu (Alongi, 2002; Field, 1995).

Penelitian terkait kondisi mangrove menyebutkan bahwa adanya degradasi terhadap mangrove yang memprihatinkan di seluruh belahan dunia. Sejak tahun 1980 sampai 2000 mangrove di dunia mengalami degradasi sebesar 25\% dari keseluruhan luasan (Giri et al., 2007; Giri et al., 2011; FAO, 2007). Penelitian yang dilakukan di Indonesia (Fajri et al., 2012; Hastiana et al., 2010; Karyono et al., 2013) menginformasikan bahwa hutan mangrove telah mengalami degradasi yang serius. Salah satu kawasan mangrove yang mengalami ancaman dan gangguan di Indonesia adalah mangrove di wilayah Kota Tanjung Pinang, tepatnya di Pulau Dompak yang memiliki ekosistem mangrove yang cukup luas. Dengan adanya kegiatan pembangunan yang cukup pesat di Kota Tanjung Pinang sebagai ibu kota provinsi, mengakibatkan Pulau Dompak menjadi kawasan pengembangan. Hal ini menyebabkan terjadinya konversi lahan secara besar-besaran di Pulau Dompak menjadi kawasan perkantoran, perumahan masyarakat, pembangunan jalan dan infrastruktur penunjang lainnya.
Kegiatan pemantauan dan pengelolaan mangrove perlu dilakukan untuk mengetahui tingkat perubahan yang terjadi dan menganalisis daerah yang perlu dilakukan perbaikan secara berkelanjutan (Abd-El Monsef \& Smith, 2017). Pemantauan hutan mangrove dilapangan memiliki kesulitan, dibutuhkan teknologi dan metode yang tepat untuk mendapatkan data spasial dan informasi mangrove secara akurat. Aplikasi teknologi pengindraan jauh berbasis citra satelit merupakan metode yang banyak dipakai untuk kegiatan pemantauan kondisi suatu daerah dan dapat menyediakan data secara efektif dan efisien berbasis spasial, seperti yang dilakukan beberapa peneliti (Giri et al., 2011; Huemann, 2011).

Klasifikasi citra satelit pengindraan jauh biasanya menggunakan pendekatan berbasis piksel, kekurangan dari pendekatan ini akan menimbulkan efek salt and pepper dan memberikan efek variasi nilai spektral yang berlebih sehingga hasil akurasi yang diperoleh rendah (Liu \& Xia, 2010). Saat ini pendekatan klasifikasi citra satelit berbasis objek (OBIA) mulai dikembangkan, pendekatan ini dianggap lebih baik dalam memberikan hasil akurasi dibandingkan pendekatan berbasis piksel (Blaschke, 2010). Menurut Myint et al. (2011) klasifikasi berbasis piksel hanya bertumpu pada nilai spektral, sedangkan OBIA mengklasifikasi citra satelit berdasarkan nilai spektral, tekstur, bentuk dan parameter lainnya (Blaschke et al., 2014). Pendekatan klasifikasi OBIA dapat mendefinisikan kelaskelas objek berdasarkan aspek spektral dan spasial secara bersamaan (Danoedoro, 2012). Klasifikasi OBIA merupakan pendekatan yang terdiri dari dua tahapan yaitu proses pembentukan segmen dan penetapan kelaskelas pada area yang telah disegmentasi (Blaschke, 2010). Segmentasi merupakan dasar dari proses klasifikasi OBIA untuk menghasilkan segmen atau objek yang selanjutnya objek tersebut akan ditetapkan pada kelas tertentu dalam proses klasifikasi. 
Klasifikasi citra satelit membutuhkan suatu algoritma untuk menghasilkan kelaskelas tertentu yang diinginkan, menurut Kuenzer et al. (2011) algoritma yang sering digunakan adalah Maximum likelihood. Hendrawan et al. (2018) memetakan mangrove menggunakan citra Landsat 8 dan algoritma maximum likelihood dengan akurasi yang diperoleh sebesar $83 \%$. Algoritma lain yang sering digunakan adalah SVM (Support Vector Machine), SVM dinilai dapat memberikan hasil yang cukup baik (Madanguit et al., 2017). Alimudi et al. (2017) memetakan mangrove menggunakan citra Landsat 7 dan algoritma SVM dengan akurasi yang diperoleh sebesar 88\%. Selain itu algoritma yang juga digunakan untuk memetakan mangrove adalah decision tree (Firmansyah et al., 2019) dan random forest (Jhonnerie et al., 2014) akurasi yang diperoleh sebesar $91,09 \%$ dan $88,4 \%$ secara berurutan.

Pemanfaatan citra satelit Sentinel 2 yang diluncurkan pada tahun 2017 belum banyak dilakukan, sehingga menjadi peluang untuk mengetahui kemampuannya dalam memetakan mangrove. Terkait dengan hal tersebut, penelitian dan literatur pengaplikasian metode klasifikasi berbasis objek (OBIA) dengan menggunakan citra satelit tersebut masih jarang dijumpai sehingga menjadi peluang digunakan pada penelitian ini untuk memetakan dan kegiatan pemantauan hutan mangrove. Oleh karenanya, tujuan penelitian ini adalah menganalisis perubahan tutupan mangrove berdasarkan klasifikasi berbasis objek (OBIA) menggunakan citra satelit SPOT 4 dan Sentinel 2B.

\section{METODE PENELITIAN}

\subsection{Waktu dan Lokasi Penelitian}

Penelitian ini dilaksanakan di Pulau Dompak Provinsi Kepulauan Riau pada bulan September-Oktober 2018. Pulau Dompak adalah pulau yang dijadikan sebagai tempat pusat pemerintahan Provinsi
Kepulauan Riau yang terletak di Kota Tanjung Pinang. Pulau ini berada di arah selatan dari pusat kota dan memiliki luas sekitar 995 ha. Peta lokasi penelitian dapat dilihat pada Gambar 1.

\subsection{Pengumpulan Data}

Pengambilan data lapangan menggunakan GPS Garmin 78s, jumlah sampel yang diambil sebanyak 130 untuk klasifikasi dan 181 untuk uji akurasi, metode yang digunakan adalah simple random sampling. Data lapangan yang diperlukan adalah titik koordinat, jenis mangrove, dan persentase tutupan kanopi mangrove yang diambil di dalam transek yang dibangun dilapangan sesuai dengan resolusi spasial citra satelit berukuran 10 x $10 \mathrm{~m}$. Sampel yang diambil untuk analisis tutupan kanopi sebanyak 36 transek. Identifikasi jenis mangrove merujuk pada buku panduan pengenalan mangrove Indonesia (Noor et al., 2012) dan analisis persentase tutupan kanopi mangrove mengacu pada panduan pemantauan status ekosistem Mangrove (LIPI, 2014).

Metode berbasis foto atau yang dikenal dengan hemispherical photography digunakan untuk memperoleh persentase tutupan kanopi mangrove dilapangan, empat foto yang diambil kemudian dianalisis menggunakan aplikasi ImageJ dan selanjutnya hasil persentase dihitung rataratanya. Analisis ini merupakan analisis berdasarkan gambar biner yang tujuannya memisahkan piksel tutupan kanopi dan langit, untuk kemudian piksel tutupan kanopi dapat diketahui persentasenya (Chianucci et al., 2014). Persentase tutupan kanopi dihitung menggunakan persamaan (1):

$\mathrm{P} 225 / \sum \mathrm{P} \times 100 \%$

Keterangan: P225 merupakan jumlah piksel yang bernilai 225, $\Sigma$ Pmerupakan jumlah total piksel dalam satu foto. 


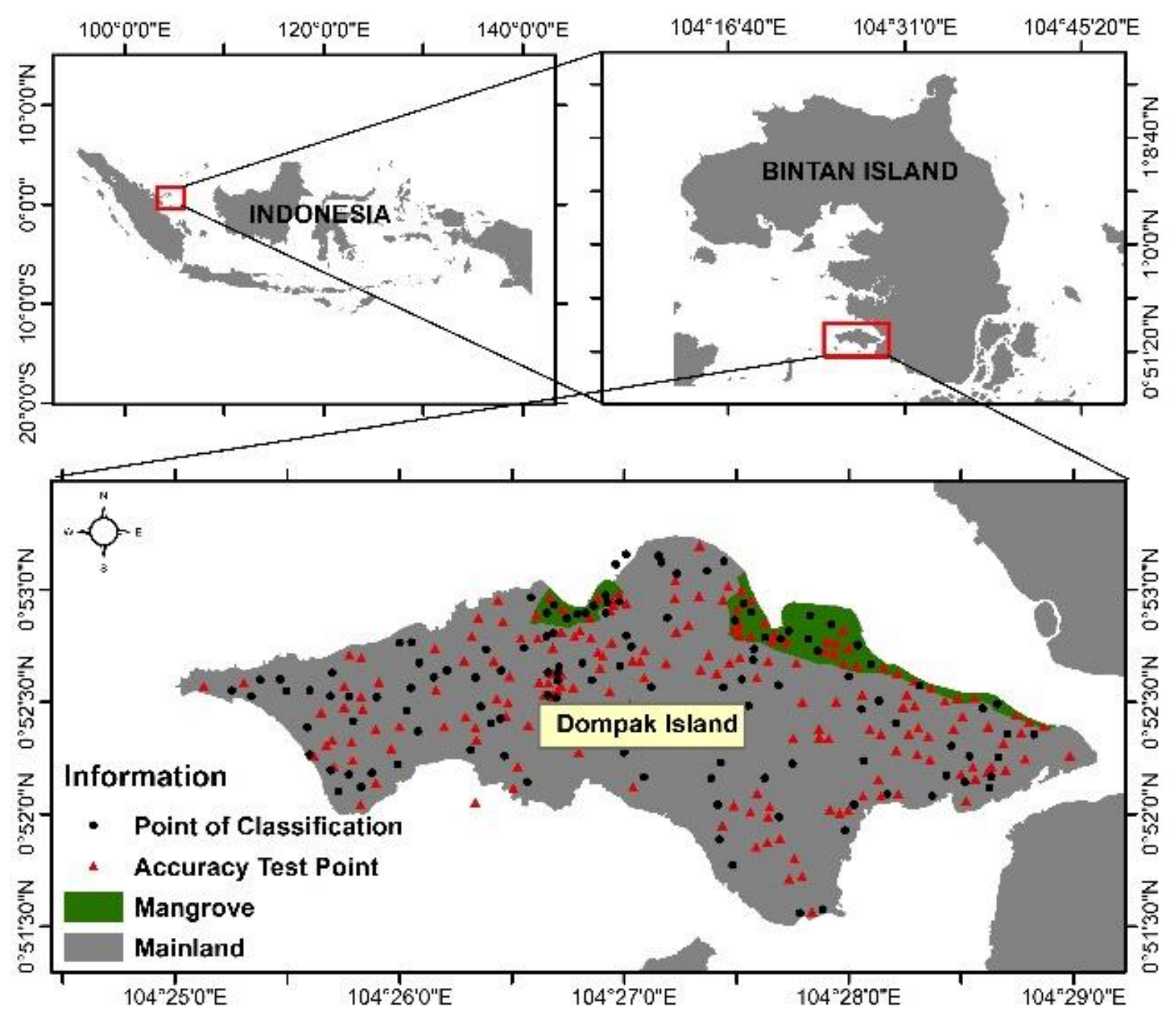

Gambar 1. Lokasi penelitian di Pulau Dompak, Kota Tanjung Pinang, Provinsi Kepulauan Riau, Indonesia.

Figure 1. Research location in Dompak Island, Tanjung Pinang City, Province of Kepulauan Riau, Indonesia.

Hasil dari analisis hemispherical photography adalah persentase yang merepresentasikan kondisi tutupan mangrove di Pulau Dompak. Kriteria persentase tutupan kanopi merujuk Keputusan Menteri Lingkungan Hidup No. 201 Tahun 2004 tentang standar baku kerusakan hutan mangrove yang dapat dilihat pada Tabel 1 .

Penelitian ini menggunakan citra satelit Sentinel-2B dan SPOT 4. Citra satelit Sentinel 2B diunduh pada laman USGS science for a changing world (https://earthexplore.usgs.gov/), sedangkan citra SPOT 4 diperoleh dari LAPAN. Data citra satelit disajikan pada Tabel 2.

Tabel 1. Kriteria persentase kondisi tutupan mangrove.

Table 1. Criteria for percentage of mangrove cover condition.

\begin{tabular}{ccc}
\hline \multicolumn{2}{c}{ Criteria } & $\begin{array}{c}\text { Percentage } \\
\text { cover } \%\end{array}$ \\
\hline Good & Dense & $>75 \%$ \\
& Medium & $50-75 \%$ \\
Bad & Rarely & $<50 \%$ \\
\hline
\end{tabular}

Source: Minister of Environment Decree No. 201 of 2004. 
Tabel 2. Spesifikasi data citra satelit.

Table 2. Satellite image data specifications.

\begin{tabular}{lccc}
\hline \multicolumn{1}{c}{ Satellite Image Type } & Spatial Resolution & Acquisition Time & Path and Row \\
\hline Sentinel $2 B$ & $10 \mathrm{~m}$ & 20 October 2018 & 125 and 59 \\
SPOT 4 & $10 \mathrm{~m}$ & 21 June 2007 & 125 and 59 \\
\hline
\end{tabular}

Source: https://earthexplore.usgs.gov/ and LAPAN).

\subsection{Analisis Data}

Tahap pertama klasifikasi OBIA yaitu pembentukan segmentasi, yaitu menghasilkan segmen-segmen hasil dari pemisahan citra satelit berdasarkan kesamaan nilai spektral dan spasial (Stow et al., 2008). Algoritma multiresolution segmentation digunakan dalam proses segmentasi ini, penggunaan aturan atau rule set parameter scale, shape dan compactness tidak punya ketetapan pasti atau baku, sehingga proses uji coba pengulangan ditentukan oleh pengguna sendiri hingga mendapatkan hasil terbaik yang diharapkan. Berikut ini disajikan pada Gambar 2 tahapan proses dalam klasifikasi OBIA.
Algoritma klasifikasi SVM digunakan untuk memperoleh kelas hasil klasifikasi, kelas yang dibentuk adalah kelas berdasarkan lokasi penelitian yaitu badan air, jalan, lahan terbuka, mangrove, pemukiman dan vegetasi. Menurut Zhu \& Blumberg (2002) sistem kerja SVM yaitu mencari hyperplane terbaik pada dua data atau lebih yang memanfaatkan data pada titik pemisah (super vector) bahkan dengan jumlah data yang terbatas. Penentuan hyperplane pemisah terbaik antara kedua kelas data yaitu dengan cara mengukur margin hyperplane untuk mencari titik maksimal. Margin merupakan jarak antara hyperplane dengan pattern terdekat dari setiap kelas. Pattern yang paling dekat

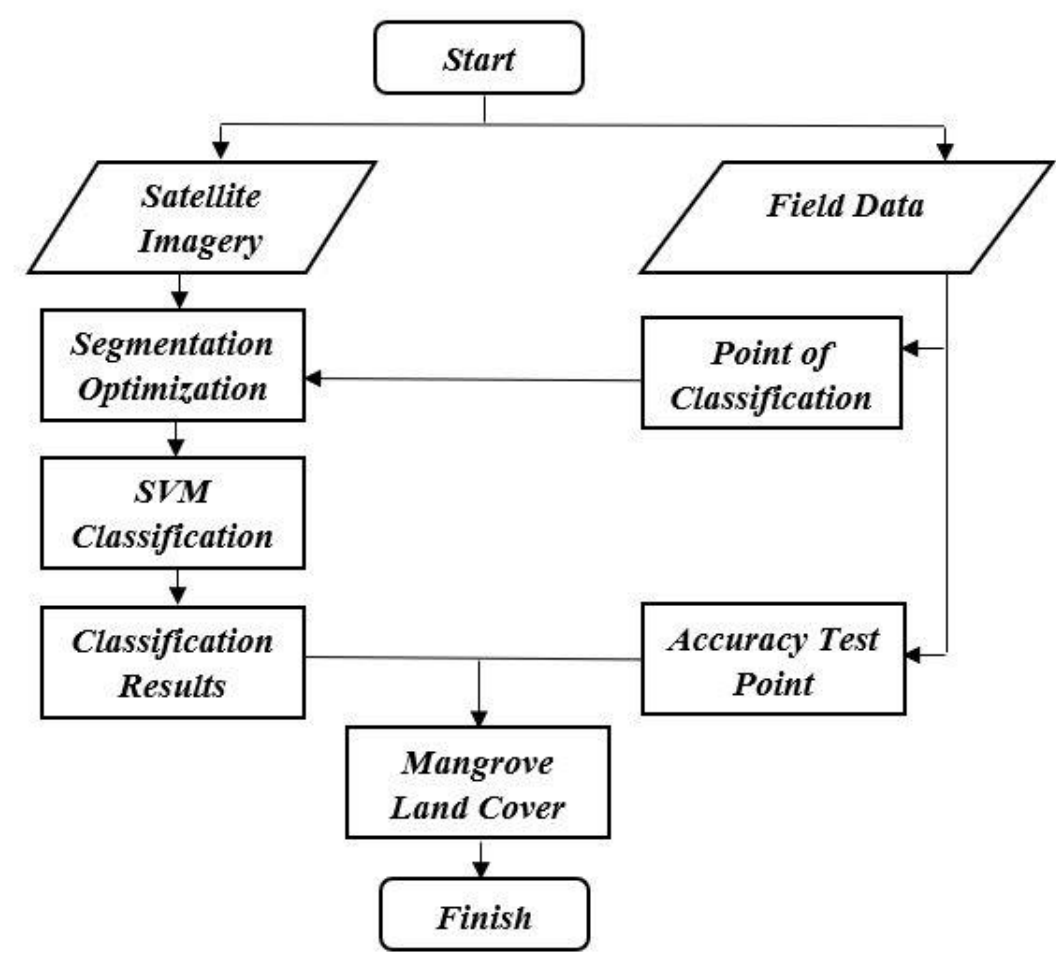

Gambar 2. Diagram alir analisis data menggunakan metode klasifikasi OBIA.

Figure 2. Flowchart of data analysis using the OBIA classification method. 
dengan garis hyperplane disebut sebagai support vector (Nugroho et al., 2003). Formula algoritma support vector machine dapat ditulis sebagai berikut (Tzotzos, 2006):

$f(x)=\sum i \in s i$ yi $K(x i x)+w 0$

Keterangan: $K$ merupakan fungsi kernel, $y_{i}$ dan $x_{i}$ mewakili sampel pelatihan, $\lambda_{i}$ merupakan pengganda Lagrange, $S$ bagian dari sampel pelatihan yang sesuai dengan pengganda Lagrange non-zero, dan wo adalah parameter hyperplane.

NDVI merupakan citra hasil transformasi yang digunakan untuk mengetahui kerapatan kanopi suatu vegetasi. Rasio band yang digunakan adalah band inframerah dekat dan band merah, nilai NDVI berkisar -1 sampai +1 , vegetasi yang sehat memiliki nilai NDVI yang tinggi begitu juga sebaliknya. Nilai negatif merepresentasikan objek air, nilai yang mendekati +1 merupakan objek vegetasi (Pujiono et al., 2013). persamaan NDVI dapat ditulis sebagai berikut:

NDVI $=\frac{\text { (Inframerah dekat }- \text { merah })}{(\text { inframerah dekat }+ \text { merah })}$

Citra hasil klasifikasi selanjutnya akan dilakukan uji akurasi, hal ini dilakukan untuk mengetahui ketepatan hasil dari klasifikasi yang telah dilakukan. Jumlah sampel yang diambil untuk uji akurasi sebanyak 181 titik. Pada umumnya uji akurasi dilakukan menggunakan suatu metode yang disebut confusion matrix, sistem kerjanya yaitu dengan membandingkan hasil klasifikasi dengan data hasil pengamatan di lapangan. Uji akurasi mengacu pada Congalton \& Green (2009) yang terdiri dari overall accuracy, producer accuracy dan user accuracy. Secara matematis dapat ditulis dengan persamaan sebagai berikut:

Producer accuracy $=\frac{x_{k k}}{x_{k+}} \times 100 \%$

$$
\begin{aligned}
& \text { User accuracy }=\frac{x_{k k}}{x_{+k}} \times 100 \% \ldots \ldots \\
& \text { Overall accuracy }=\frac{\sum x_{k k}}{N} \times 100 \%
\end{aligned}
$$

Kappa statistik merupakan sebuah perhitungan yang digunakan untuk mengevaluasi akurasi dari tutupan lahan yang dihasilkan oleh matriks kesalahan dengan persamaan berikut (Congalton \& Green, 2009) :

Kappa accuracy $=\frac{N \sum_{k}^{r} x_{k k}-\sum_{k}^{r} x_{k+} x_{+k}}{N^{2}-\sum_{k}^{r} x_{k+} x_{+k}} \ldots$

Keterangan: $X_{k k}$ nilai terklasifikasi secara tepat, $X_{k+}$ nilai total kolom setiap kelas, $X_{+k}$ nilai total baris setiap kelas, $\sum X_{k k}$ jumlah nilai yang terklasifikasi secara tepat, $N$ banyaknya total data yang diperoleh, $\sum_{k}^{r} X_{k+} X_{+k}$ setiap jumlah total $\mathrm{x}$ jumlah kolom.

\section{HASIL DAN PEMBAHASAN}

Pulau Dompak merupakan pulau yang dijadikan sebagai pusat pemerintahan Provinsi Kepulauan Riau sejak tahun 2007, pembangunan yang cukup pesat di pulau ini menyebabkan terjadinya konversi lahan termasuk lahan mangrove yang dijadikan untuk daerah perkantoran, perumahan masyarakat, pembangunan jalan dan infrastruktur pendukung lainnya. Hasil pengamatan di lapangan ditemukan 14 jenis spesies mangrove yaitu Acanthus ilicifolius, Avicennia lanata, Bruguiera cylindrical, B. gymnorrhiza, Ceriops tagal, Lumnitzera littorea, L. racemosa, Nypa fruticans, Pandanus tectorius, Rhizophora apiculata, $R$. mucronata, Scaevola taccada, Scyphiphora hydrophyllacea dan Xylocarpus granatum.

Hasil analisis hemisperichal photography yang diambil pada 36 transek (titik sampel) menunjukkan bahwa kondisi hutan mangrove di Pulau Dompak 
Tabel 3. Persentase tutupan kanopi transek 10 x 10 m pada Citra Sentinel 2B.

Table 3. Percentage of transect canopy cover $10 \times 10 \mathrm{~m}$ in Sentinel 2B Imagery.

\begin{tabular}{cccccc}
\hline Transect & Criteria $(\%)$ & Transect & Criteria $(\%)$ & Transect & Criteria $(\%)$ \\
\hline 1 & 84.77 & 13 & 49.59 & 25 & 88.3 \\
2 & 88 & 14 & 85.43 & 26 & 86.81 \\
3 & 86.79 & 15 & 42.98 & 27 & 89.72 \\
4 & 82.11 & 16 & 83.6 & 28 & 87.83 \\
5 & 92.72 & 17 & 88.68 & 29 & 87.5 \\
6 & 95.16 & 18 & 84.26 & 30 & 38.49 \\
7 & 94.75 & 19 & 89.91 & 31 & 87.89 \\
8 & 95.12 & 20 & 85.75 & 32 & 85.1 \\
9 & 93.26 & 21 & 78.73 & 33 & 86.76 \\
10 & 92.55 & 22 & 89.7 & 34 & 28.53 \\
11 & 43.11 & 23 & 89.54 & 35 & 91.02 \\
12 & 46.76 & 24 & 90.13 & 36 & 90.31 \\
\hline
\end{tabular}

Information: percentage $<50 \%$ (rare), persentase $>75 \%$ (dense).

dikategorikan jarang dan lebat dengan dominansi kategori lebat. Hasil rata-rata persentase tutupan kanopi mangrove dapat dilihat pada Tabel 3.

\subsection{Segmentasi Citra Satelit}

Proses segmentasi tidak ada aturan pasti terkait input parameternya, sehingga pengguna harus melakukan optimasi skala untuk mendapatkan hasil yang terbaik. Optimasi skala segmentasi yang digunakan dalam penelitian ini adalah skala 3, 5, 7, 9, 11, 13, 15 dan 17 dengan nilai shape dan compactness 0,1 dan 0,5 secara berurutan. Nilai akurasi yang diperoleh dari tiap segmentasi yang digunakan secara berurutan didapatkan hasil sebagai berikut $89 \%, 88,4 \%$, $87,3 \%, 87,8 \%, 86,2 \%, 88,4 \%, 88,4 \%$ dan $85,1 \%$.

Skala segmentasi sangat berpengaruh terhadap bentuk segmen yang akan dihasilkan, semakin besar nilai skala misalnya 17 akan menghasilkan segmen yang besar dan homogenitasnya tinggi. Begitupun sebaliknya, jika skala segmentasi kecil misalnya 3 maka akan menghasilkan bentuk segmen yang kecil pula dan cenderung heterogen. Proses pemahaman pengaruh skala segmentasi terhadap segmen yang terbentuk, berikut ditampilkan hasil pembentukan segmen dengan skala 3, 9 dan 17 pada citra Sentinel 2B dan skala 3 pada citra SPOT 4 yang dapat dilihat pada Gambar 3.

Skala segmentasi juga memengaruhi jumlah segmen yang akan dihasilkan (Gambar 4), semakin kecil skala misalnya 3 akan menghasilkan jumlah segmen sebanyak 126777 dan sebaliknya jika skala semakin besar misalnya 17 akan menghasilkan jumlah segmen yang lebih sedikit yaitu 11154 . Rosmasita et al. (2018) pada penelitiannya mendapatkan hal yang serupa pada skala segmentasi yang kecil, jumlah segmentasi akan lebih banyak dan sebaliknya pada skala segmentasi besar, jumlah segmentasi lebih sedikit. Optimasi skala segmentasi selama pengolahan data akan menghasilkan akurasi terbaik, akurasi terbaik yang diperoleh yaitu pada skala 3 dengan overall akurasi 89\%, dengan nilai shape dan compactness 0,1 dan 0,5 secara berurutan. Nilai akurasi yang dihasilkan tidak hanya dipengaruhi secara mutlak oleh skala segmentasi tetapi juga dipengaruhi oleh resolusi spasial dan spektral citra, jumlah kelas objek, sampel objek segmentasi, dan algoritma yang digunakan (Wahidin et al., 2015). Hubungan antara skala dan jumlah segmen yang dihasilkan dapat dilihat pada Gambar 4. 

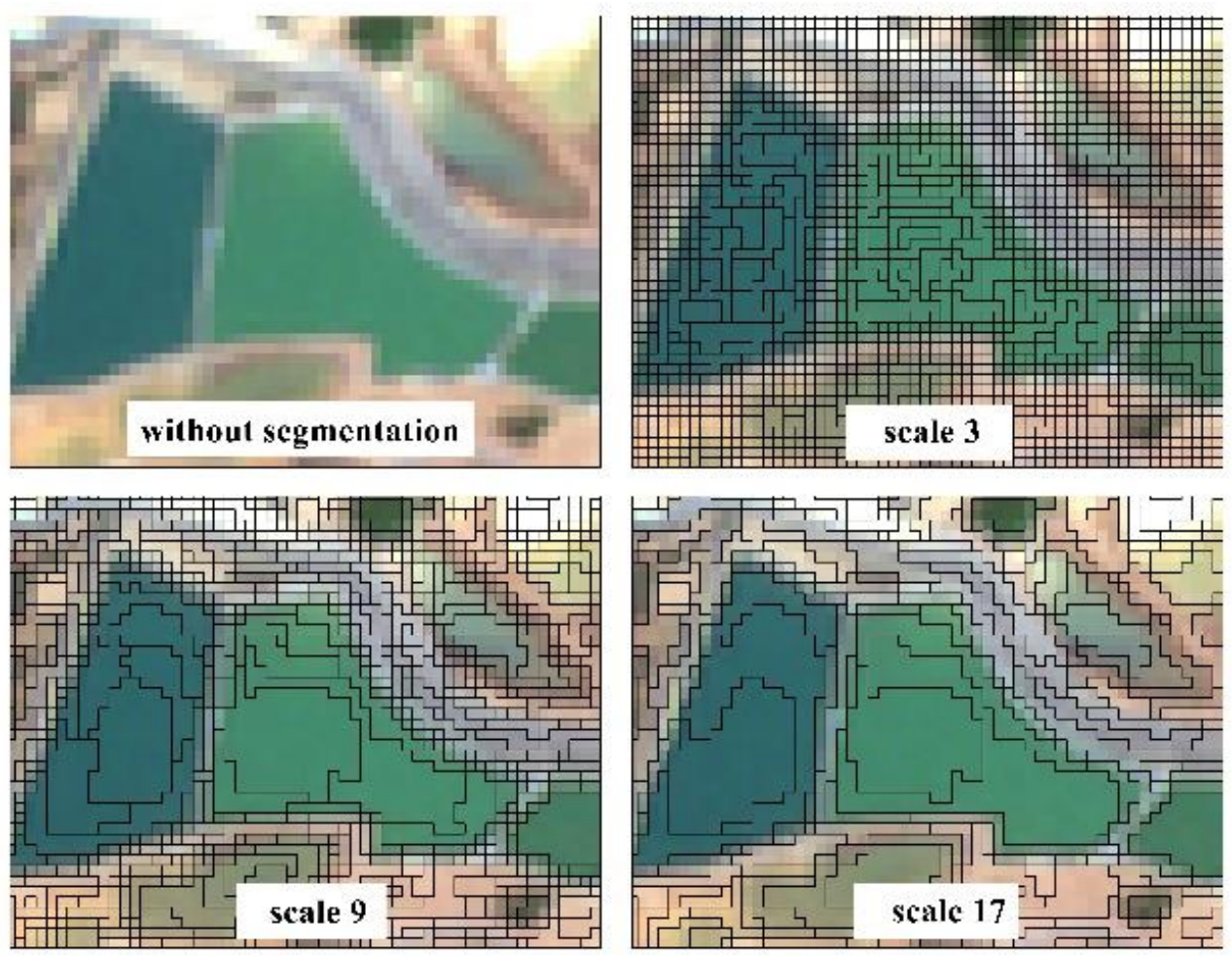

(a)
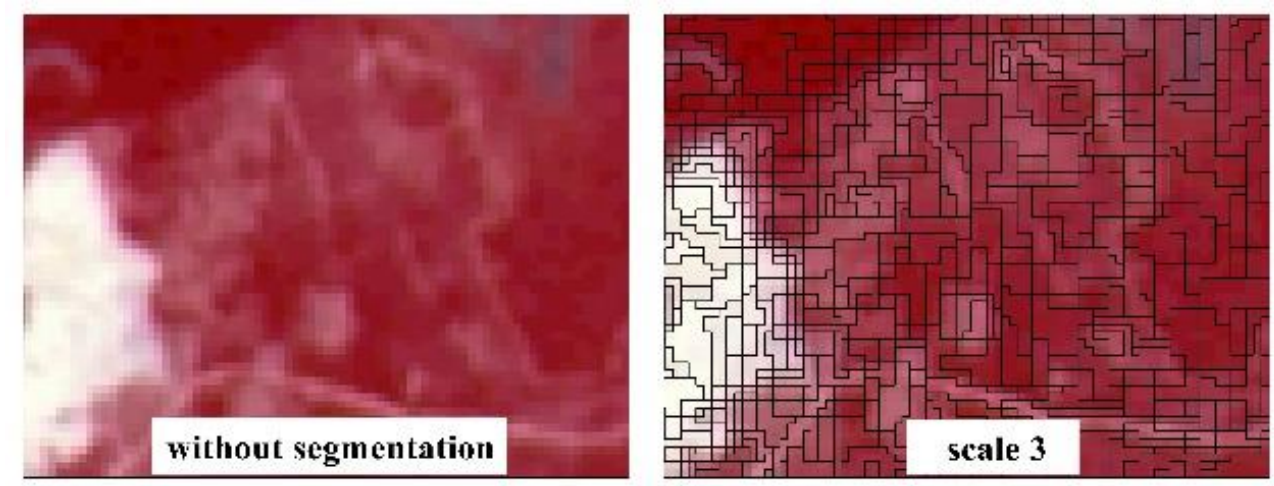

(b)

Gambar 3. Hasil segmentasi dengan skala berbeda pada citra (a) Sentinel 2B (b) SPOT 4.

Figure 3. The results of segmentation with different scales on the image (a) Sentinel $2 B(b)$ SPOT 4.

\subsection{Hasil Klasifikasi Citra}

Klasifikasi OBIA cukup efektif digunakan dalam penelitian ini untuk memetakan tutupan lahan dan sebaran mangrove, teknik ini merupakan pendekatan alternatif lain yang dikembangkan dengan konsep berbasis objek dan tidak hanya berdasarkan nilai piksel melainkan juga nilai skala, bentuk dan kekompakkan. Blaschke
(2010) menyatakan bahwa objek atau segmentasi pada citra merupakan sekumpulan beberapa piksel dengan nilai spektral dan spasial yang sama. Pendekatan hasil klasifikasi OBIA yang didapatkan menunjukkan objek mangrove dapat dipetakan dengan baik (Gambar 5). Selain itu tingginya nilai pada keseluruhan akurasi yang dihasilkan (Tabel 4) mengindikasikan 


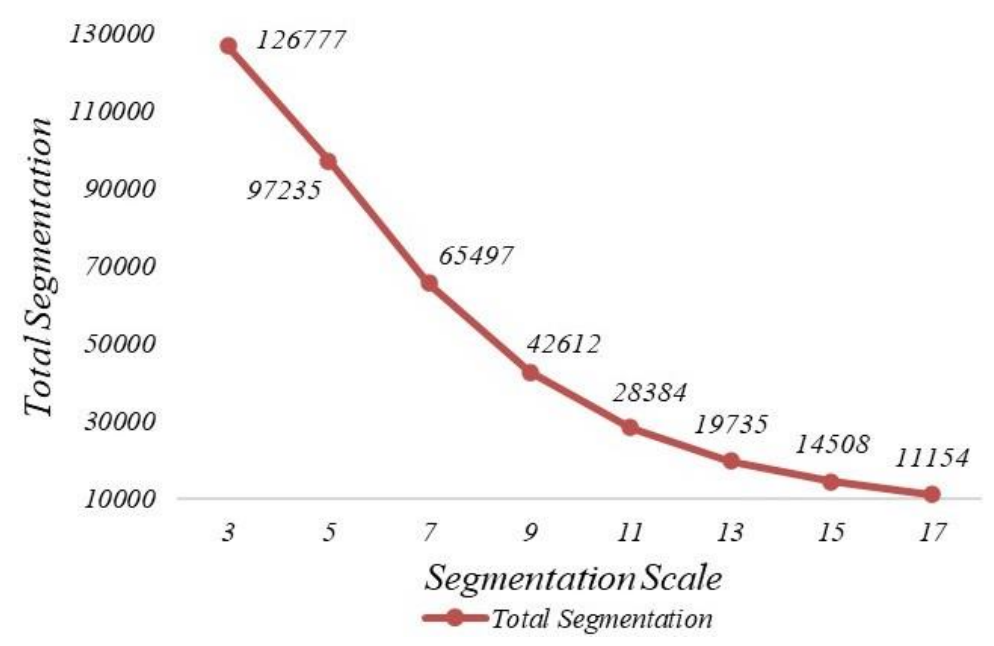

Gambar 4. Pengaruh skala dan total segmen.

Figure 4. Effect of scale and total of segments.

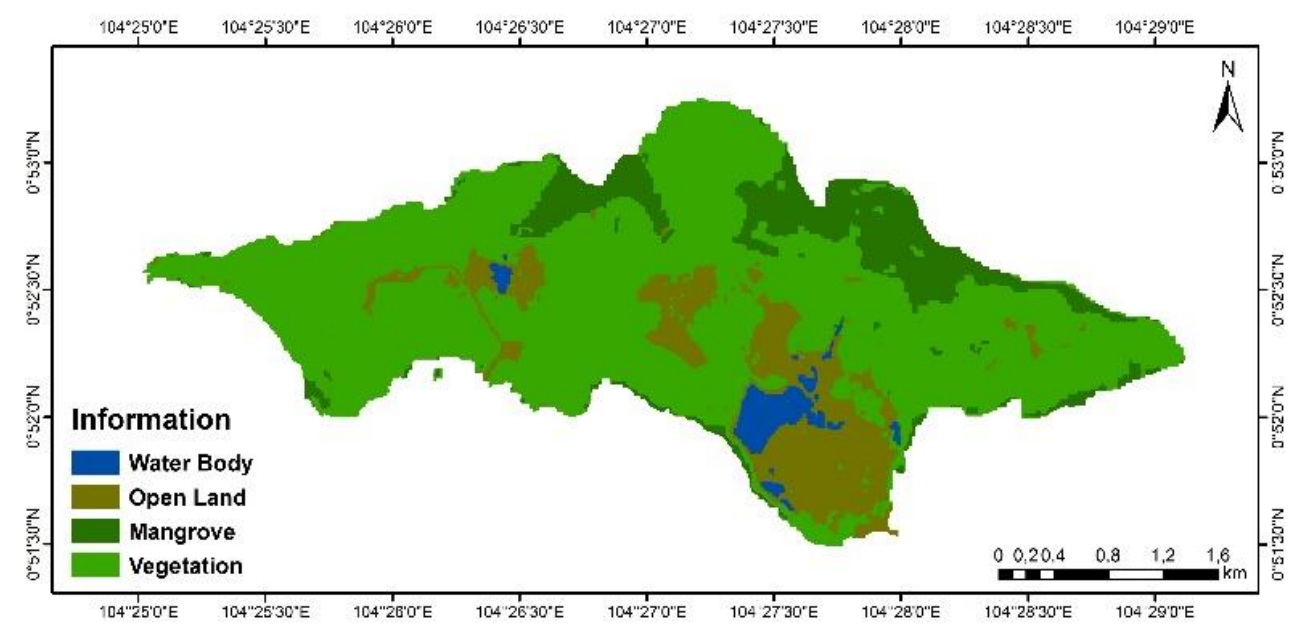

(a)

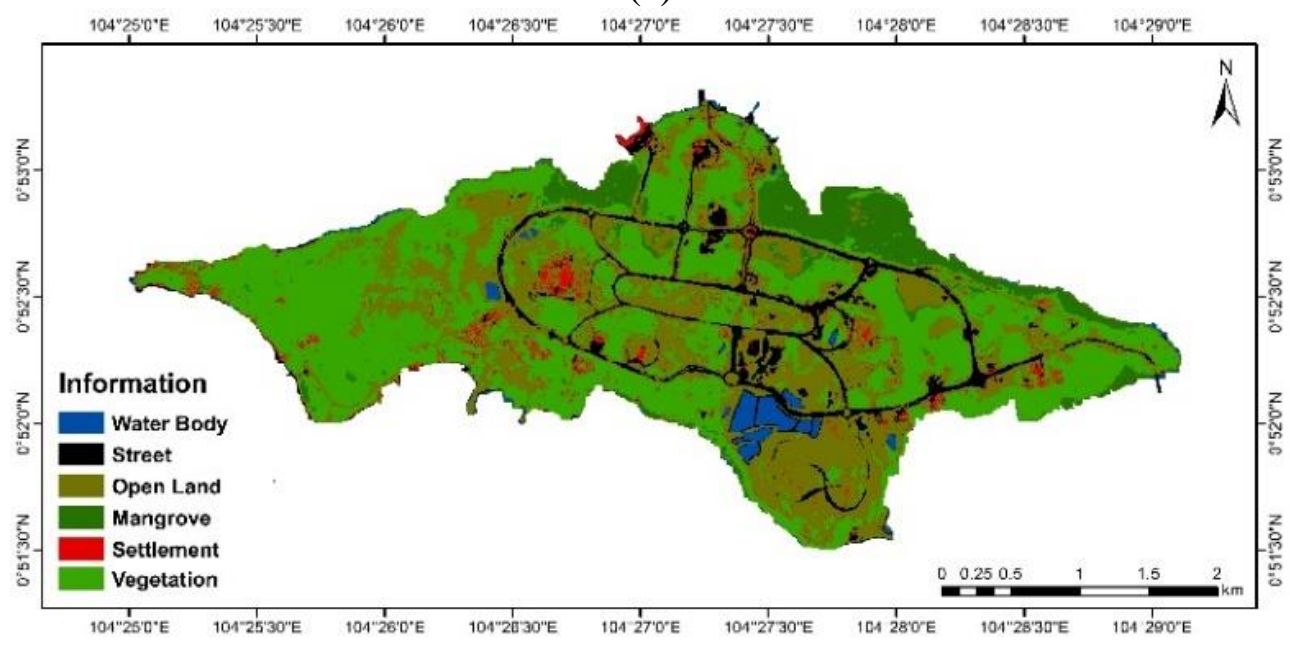

(b)

Gambar 5. Hasil klasifikasi citra (a) SPOT 42007 (b) Sentinel 2B 2018.

Figure 5. Image classification results (a) SPOT 42007 (b) Sentinel 2B 2018. 
bahwa pendekatan klasifikasi OBIA sangat baik untuk dijadikan sebagai alternatif dalam memetakan mangrove dan tutupan lahan yang ada di sekitarnya. Kendati demikian, masih ditemukan kesalahan dalam pemisahan kelas mangrove terhadap kelas lainnya. Menurut Conchedda et al. (2008) ada beberapa kemungkinan penyebab masih terdapatnya kesalahan dalam pemisahan objek mangrove dengan objek lainnya, yaitu penutupan lahan yang berada di sekitar kawasan mangrove menempati kawasan morfologi yang sama. Hal ini menyebabkan sulit untuk membedakan kemiripan spektral saat pemilihan sampel objek untuk membangun kelas yang spesifik. Hasil pendekatan klasifikasi OBIA dapat dilihat pada Gambar 5.

Berdasarkan Gambar 5a citra SPOT 4 tahun 2007 diklasifikasikan menjadi 5 kelas yaitu badan air, lahan terbuka, mangrove, vegetasi dan laut, berbeda dengan citra Sentinel 2B tahun 2018 Gambar 5b yang dikelaskan menjadi 7 kelas yaitu badan air, jalan, lahan terbuka, mangrove, pemukiman, vegetasi, dan laut, hal ini dikarenakan pada citra SPOT 4 tahun 2007 tidak ditemukannya kelas jalan dan pemukiman. Klasifikasi OBIA dengan menerapkan algoritma SVM menunjukkan hasil yang sesuai dengan kondisi asli baik di citra maupun di lapangan, hal ini dikarenakan algoritma SVM dapat menghasilkan akurasi yang baik dengan kemampuannya mengurangi kesalahan dalam klasifikasi citra (Cao et al., 2018), kemampuan SVM untuk mencari titik maksimal dan garis pemisah hyperplane terbaik inilah yang menyebabkan hasil klasifikasi dan akurasi yang didapatkan baik. Shafri et al. (2009) melakukan penelitian dengan algoritma SVM mendapatkan akurasi sebesar $73 \%$, penelitian lainya Cao et al. (2018) mendapatkan akurasi sebesar 89,55\%

Selain penerapan klasifikasi OBIA dan algoritma SVM, jumlah kelas juga memengaruhi nilai akurasi. Dwiputra et al. (2016) mendapatkan hasil akurasi 4 kelas sebesar $87,27 \%, 7$ kelas 79,80\% dan 10 kelas sebesar 73,34\%. Penggunaan citra satelit Sentinel 2B dalam penelitian ini dengan resolusi 10 x $10 \mathrm{~m}$ juga memberikan pengaruh terhadap hasil akurasi, Mallinis et al. (2018) mendapakan hasil akurasi citra Sentinel 2B lebih baik dari citra Landsat yaitu sebesar $73,33 \%$ sedangkan citra Landsat hanya $71,11 \%$. Hasil uji akurasi klasifikasi dapat dilihat pada Tabel 4.

Uji akurasi menunjukkan hasil yang memuaskan, nilai akurasi keseluruahan (OA) yaitu $89 \%$ dan nilai statistik Kappa 0,86 (Tabel 4). Hasil akurasi yang diperoleh tidak berbeda jauh dengan penelitian sebelumnya, seperti Alimudi et al. (2017) memetakan mangrove menggunakan pendekatan klasifikasi OBIA pada citra Landsat dengan mendapatkan akurasi keseluruhan sebesar $88 \%$. Hasil yang diperoleh terlihat jelas bahwa pemetaan mangrove menggunakan teknik klasifikasi berbasis objek (OBIA) merupakan salah satu alternatif yang menjanjikan.

\subsection{Indeks Vegetasi NDVI}

Citra transformasi NDVI menghasilkan citra baru yang berisi informasi terkait tingkat kerapatan kanopi mangrove. Rentang nilai NDVI yang diperoleh adalah 0.550413 sampai 0.772189 , selanjutnya rentang nilai tersebut dilakukan pengkelasan untuk mendapatkan batas nilai objek badan air, non vegetasi dan vegetasi. Pengkelasan dilakukan berdasarkan data lapangan dan visualisasi citra RGB true color.

Kelas vegetasi selanjutnya dilakukan pengkelasan kembali untuk mengetahui batas nilai NDVI vegetasi jarang dan lebat. Pengkelasan dilakukan berdasarkan data (hemisperichal photography). Rentang nilai NDVI (-0,550 - -0,099) merupakan objek air dan $(-0,099$ - 0,305) merupakan objek lahan terbuka atau non vegetasi sedangkan nilai di atas $(>0,305)$ adalah objek vegetasi. Perbedaan nilai ini disebabkan karena setiap objek tersebut memiliki nilai spektral (NDVI) yang berbeda. Rentang nilai NDVI yang diperoleh disajikan pada Tabel 5. 
Tabel 4. Hasil pengujian akurasi klasifikasi citra Sentinel 2B.

Table 4. The results of the Sentinel $2 B$ image classification accuracy test results.

\begin{tabular}{|c|c|c|c|c|c|c|c|c|}
\hline \multicolumn{9}{|c|}{ Reference data } \\
\hline Classification & $B A$ & $J$ & $L T$ & $M$ & $P$ & $V$ & Total & $U A(\%)$ \\
\hline$B A$ & 8 & & & & & & 8 & 100 \\
\hline$J$ & & 17 & 2 & & 1 & & 20 & 85 \\
\hline$L T$ & & 5 & 32 & & 8 & & 45 & 71.11 \\
\hline$M$ & & & & 36 & & 2 & 38 & 94.74 \\
\hline$P$ & & & 1 & & 20 & & 21 & 95.24 \\
\hline$V$ & & & & 1 & & 48 & 49 & 97.96 \\
\hline Total & 8 & 22 & 35 & 37 & 29 & 50 & 181 & \\
\hline$P A(\%)$ & 100 & 77.27 & 91.43 & 97.30 & 68.97 & 96.00 & & \\
\hline
\end{tabular}

Information: BA (Water Body), J (Street), LT (Open Land), M (Mangrove), P (Settlements), V (Vegetation), PA (Producer Accuracy), UA (User Accuracy), OA (Overal Accuracy).

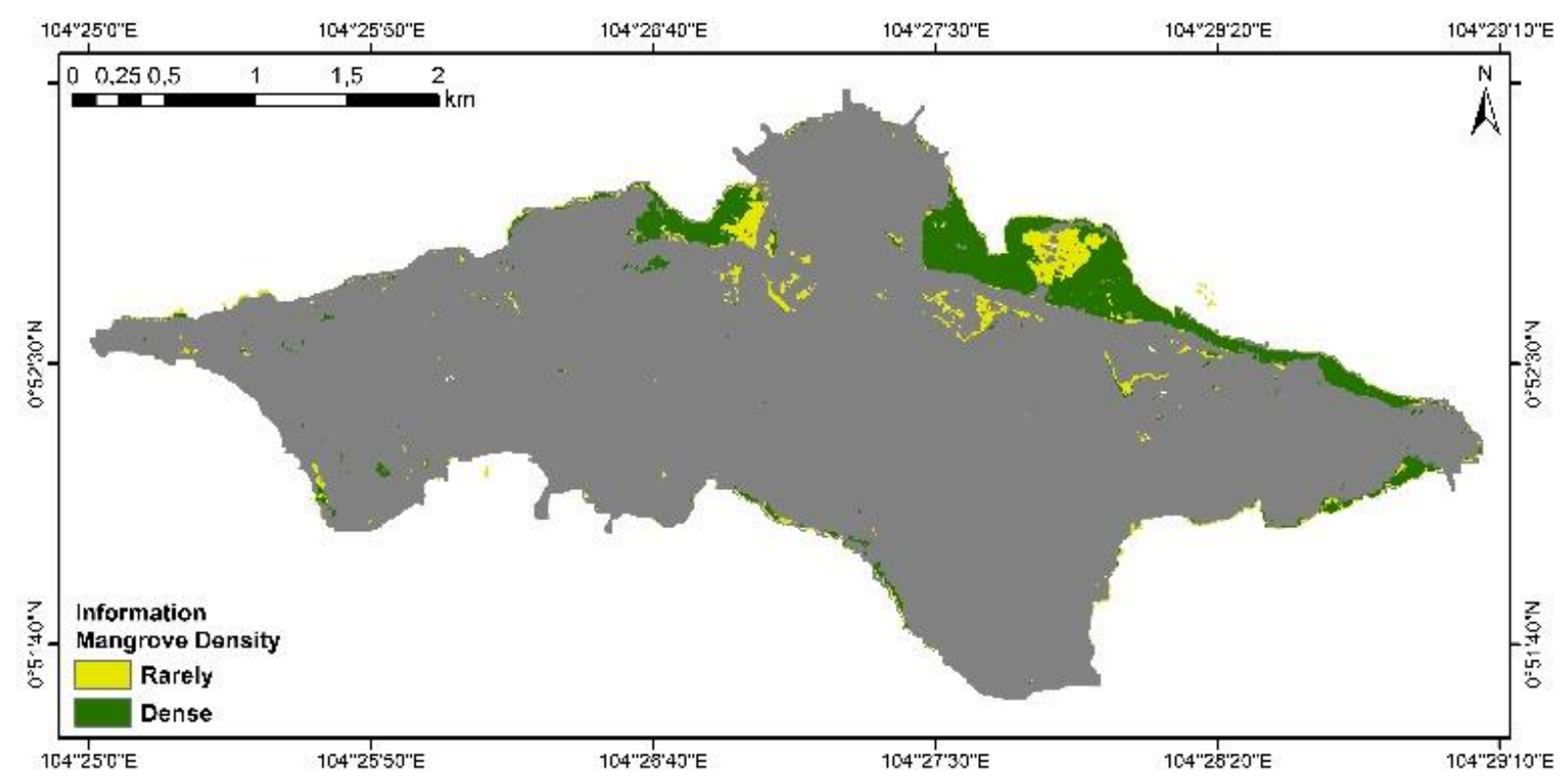

Gambar 6. Peta kerapatan kanopi mangrove Pulau Dompak.

Figure 6. Dompak Island mangrove canopy density map.

Tabel 5. Rentang nilai NDVI di Pulau Dompak.

Table 5. NDVI value range in Dompak Island.

\begin{tabular}{lc}
\hline \multicolumn{1}{c}{ Class } & NDVI value range \\
\hline Water body & $-0.550-(-0.099)$ \\
Non vegetation & $-0.099-0.305$ \\
Rarely vegetation & $0.305-0.521$ \\
Dense vegetation & $0.521-0.772$ \\
\hline
\end{tabular}

Hasil transformasi citra NDVI merepresentasikan kerapatan kanopi vegetasi secara umum, untuk memperoleh kerapatan kanopi vegetasi mangrove secara spesifik dilakukan tumpang susun (overlay) antara citra NDVI dengan hasil klasifikasi citra yang memiliki akurasi terbaik. Hasil tumpang susun (overlay) akan menghasilkan citra NDVI dengan 2 kelas kerapatan kanopi, yaitu kerapatan jarang dan lebat. Peta 
Tabel 6. Perubahan tutupan lahan Pulau Dompak 2007-2018.

Table 6. Changes in Dompak Island land cover 2007-2018.

\begin{tabular}{|c|c|c|c|c|c|}
\hline No & Land cover & $\begin{array}{l}\text { Land cover } \\
\text { area in } \\
2007 \text { (ha) }\end{array}$ & $\begin{array}{l}\text { Land cover } \\
\text { area in } \\
2018(\text { ha) }\end{array}$ & $\begin{array}{l}\text { Area of land } \\
\text { cover } \\
\text { change (ha) }\end{array}$ & Information \\
\hline 1. & Water body & 25.71 & 23.11 & -2.6 & Turned into open land \\
\hline 2. & Open land & 146.66 & 340.09 & 193.43 & Turned into open land \\
\hline 3. & Mangrove & 136.31 & 89.7 & -46.61 & $\begin{array}{l}\text { Turned into open land } \\
\text { and Street }\end{array}$ \\
\hline 4. & Vegetation & 750.35 & 493.16 & -257.19 & $\begin{array}{l}\text { Turned into open land, } \\
\text { Street and Settlements }\end{array}$ \\
\hline 5. & Settlements & 0 & 34.36 & 34.36 & Development in 2007 \\
\hline 6. & Street & 0 & 82.78 & 82.78 & Development in 2007 \\
\hline
\end{tabular}

Information: (-): Decrease (+): Increase.

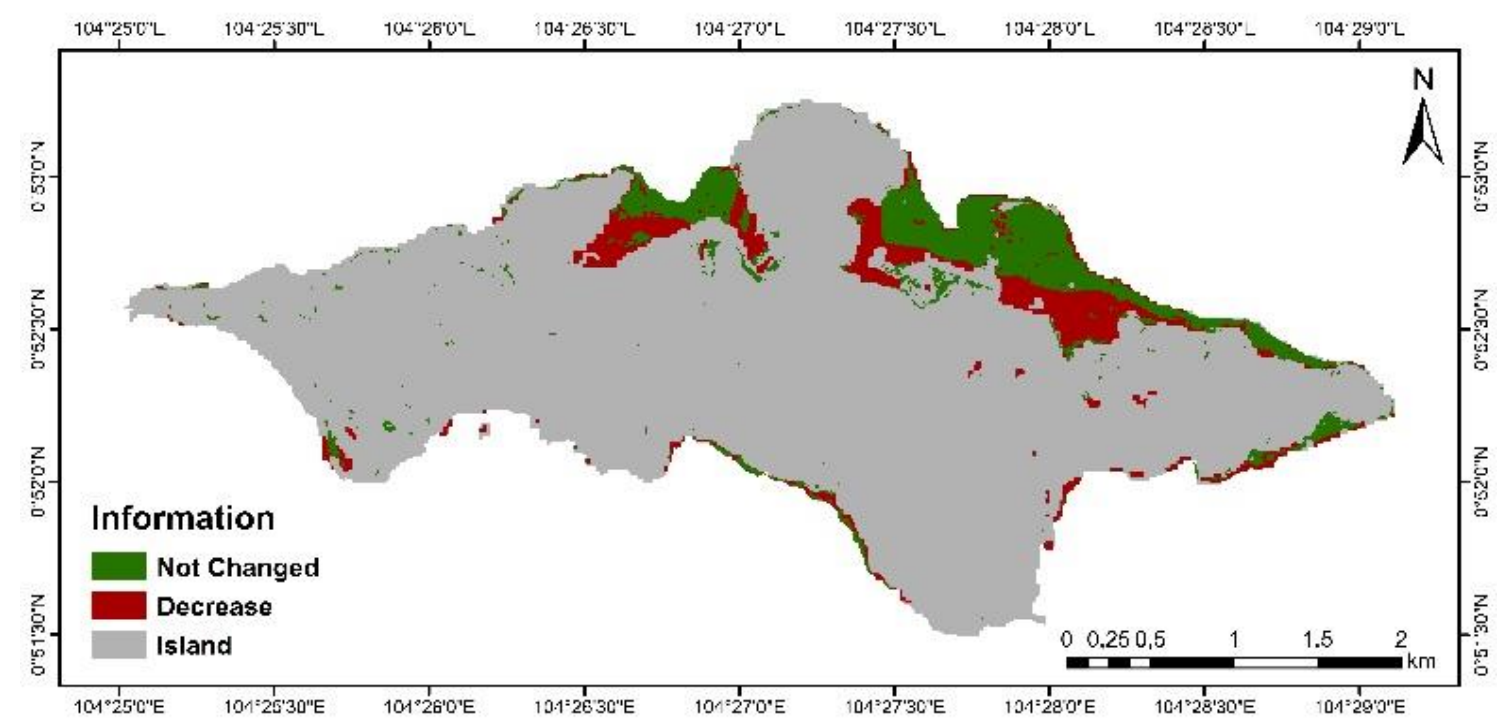

Gambar 7. Perubahan luas dan sebaran mangrove tahun 2007-2018.

Figure 7. Changes in the area and distribution of mangrove in 2007-2018.

kerapatan kanopi mangrove Pulau Dompak disajikan pada Gambar 6.

\subsection{Perubahan Luasan dan Sebaran Mangrove}

Berdasarkan analisis perubahan tutupan lahan diketahui telah terjadi perubahan penutupan lahan sejak tahun 2007 sampai 2018 (Tabel 6), diantaranya terjadi penurunan lahan mangrove, badan air dan vegetasi diikuti dengan meningkatnya lahan terbuka, pembangunan jalan dan pemukiman. Lahan mangrove mengalami penurunan dari
136,31 ha menjadi 89,7 ha, badan air turun dari 25,71 ha menjadi 23,11 ha dan lahan vegetasi turun dari 750,35 ha menjadi 493,16 ha sedangkan lahan terbuka mengalami peningkatan dari 146,66 ha menjadi 340,09 ha. Pembangunan jalan dan pemukiman sejak tahun 2007 mengakibatkan terjadinya penambahan penutupan lahan jalan dan pemukiman dengan luas masing-masing 82,78 ha dan 34,36 ha secara berurutan.

Berdasarkan Tabel 6 diketahui bahwa badan air mengalami penurunan sebesar 2,6 ha, lahan terbuka mengalami peningkatan 
sebesar 193,43 ha, luas hutan mangrove mengalami penurunan luas sebesar 46,61 ha, vegetasi mengalami penurunan luas sebesar 257,19 ha. Berdasarkan analisis data dan pengamatan lapangan, luas hutan mangrove mengalami penurunan sebesar $34,19 \%$ atau sekitar 46,61 ha yang disebabkan oleh konversi lahan (kawasan perkantoran, perumahan masyarakat, pembangunan jalan dan infrastruktur pendukung) dan penebangan. Perubahan luasan dan sebaran mangrove dapat dilihat pada Gambar 7.

\section{KESIMPULAN}

Berdasarkan analisis perubahan tutupan lahan mangrove dengan pendekatan metode OBIA, luas mangrove Pulau Dompak dari tahun 2007 sampai 2018 mengalami penurunan sebesar $34,19 \%$ atau sekitar 46,61 ha. Berdasarkan pengamatan di lapangan, hutan mangrove di lokasi penelitian dikonversi menjadi kawasan perkantoran, perumahan masyarakat, pembangunan jalan dan infrastruktur pendukung.

\section{UCAPAN TERIMA KASIH}

Terimakasih saya ucapkan kepada Pusat Teknologi dan Data Penginderaan Jauh LAPAN Jakarta yang telah mengizinkan untuk menggunakan data citra SPOT 4 tahun 2007, serta teman-teman yang telah ikut membantu pengambilan data lapangan. Penulis juga mengucapkan terima kasih kepada reviewer yang telah memberikan masukan untuk meningkatkan kualitas paper ini.

\section{DAFTAR PUSTAKA}

Abd-El Monsef, H. \& S.E. Smith. 2017. A new approach for estimating mangrove canopy cover using Landsat 8 imagery. Comput. Electron. Agr., 135: 183-194. https://doi.org/10.1016/j.compag.201 7.02.007
Alongi, D.M. 2002. Present state and future of the world's mangrove forests. Environ. Conserv., 29(3): 331-349. https://doi.org/10.1017/S0376892902 000231

Ahmad, S. 2009. Recreational values of mangrove forest in Larut Matang, Perak. J. Trop. For. Sci., 21(2): 8187. https://www.jstor.org/stable/2361663 8

Alimudi, S., S.B. Susilo, \& J.P. Panjaitan. 2017. Deteksi perubahan luasan mangrove menggunakan citra Landsat berdasarkan metode OBIA di Teluk Valentine Pulau Buano Seram bagian barat. J. Teknol. Perikanan Kelautan, 8(1): 139-146. https://doi.org/10.24319/jtpk.8.139146

Barati, S., B. Rayegani, M. Saati, A. Sharifi, \& M. Nasri. 2011. Comparison the accuracies of different spectral indices for estimation of vegetation cover fraction in sparse vegetated areas. Egyp. J. Remote Sens. Space Sci., 14: 49-56. https://doi.org/10.1016/j.ejrs.2011.06. 001

Blaschke, T. 2010. Object based image analysis for remote sensing. ISPRS. J. Photogramm, 65: 2-16. https://doi.org/10.1016/j.isprsjprs.200 9.06.004

Blaschke, T., G.J. Hay, M. Kelly, S. Lang, P. Hofmann, E. Addink, R.Q. Feitosa, F. van der Meer, $H$. van der Werff, $F$. van Coillie, et al. 2014. Geographic object-based image analysis-towards a new paradigm. ISPRS. J. Photogramm, 87: 180-191.

https://doi.org/10.1016/j.isprsjprs.201 3.09.014

Cannicci, S., D. Burrows, S. Fratini, T.J. Smith III, J. Offenberg, \& F. Dahdouh-Guebas. 2008. Faunal impact on vegetation structure and ecosystem function in mangrove 
forests: A review. Aquat. Bot., 89: 186-200.

https://doi.org/10.1016/j.aquabot.200 8.01 .009

Cao, J., W. Leng, K. Liu K, L. Liu, Z. He, \& Y. Zhu. 2018. Object-Based mangrove species classification using unmanned aerial vehicle hyperspectral images and digital surface models. Remote Sens, 10(89): $1-20$. https://doi.org/10.3390/rs10010089

Carrasquilla-Henao, M., H.A.G. Ocampo, A.L. Gonzalez, \& G.R. Quiroz. 2013. Mangrove forest and artisanal fishery in the southern part of the Gulf of California, Mexico. Ocean Coast. Manage, 83: 75-80. https://doi.org/10.1016/j.ocecoaman.2 013.02.019

Conchedda, G., D. Lauren, \& M. Phileppe. 2008. An object-based method for mapping and change analysis in mangrove ecosystem. ISPRS. J. Photogramm, 63: 578-589.

https://doi.org/10.1016/j.isprsjprs.200 8.04.002

Chianucci, F., U. Chiavetta, \& A. Cutini. 2014. The estimation of canopy attributes from digital cover photography by two different image analysis methods. iForest, 7: 255259.

https://doi.org/10.3832/ifor0939-007

Congalton, R.G. \& K. Green. 2009. Assessing the Accuracy of Remotely Sensed Data: Principles and Practices. $2^{\text {nd }}$ ed. CRC Press. Boca Raton. 183 p.

Datta, D., R.N. Chattopadhyay, \& P. Guha. 2012. Community based mangrove management: A review on status and sustainability. J. Environ. Manage., 107: 84-95.

https://doi.org/10.1016/j.jenvman.201 2.04 .013
Danoedoro, P. 2012. Pengantar Penginderaan Jauh Digital. Andi Offset. Yogyakarta. 398 hlm.

Donato, D.C., J.B. Kauffman, D. Murdiyarso, S. Kurnianto, M. Stidham, \& M. Kanninen. 2011. Mangroves among the most carbonrich forests in the tropics. Nat. Geosci., 4: 293-297. https://doi.org/10.1038/ngeo1123

Dwiputra, A.J., R. Suharyadi, \& P. Danoedoro. 2016. Pengaruh jumlah kelas dan skema klasifikasi terhadap akurasi informasi penggunaan lahan hasil klasifkasi berbasis objek dengan teknik support vector machine di sebagian Kabupaten Kebumen Provinsi Jawa Tengah. Majalah Geografi Indonesia, 30(2): 120-133. https://doi.org/10.22146/mgi.15632

Fajri, P. Subardjo, \& R. Pribadi. 2012. Studi perubahan luasan vegetasi mangrove mengunakan citra Landsat TM dan Landsat 7 ETM+ tahun 1998-2010 di pesisir kabupaten Mimika Papua. J. Mar. Res., 1(1): 146-145. https://doi.org/10.14710/jmr.v1i1.200 2

Food and Agriculture Organization (FAO). 2007. The World's Mangrove 19802005. FAO. Rome. FAO. 89 p.

Field, C.D. 1995. Impact of expected climate change on mangroves. In: Wong, Y.S. \& N.F.Y. Tam. (ed.). Asia Pacific Symposium on Mangrove Ecosystems. Springer. Kowloon, 7581 pp. https://doi.org/10.1007/97894-011-0289-6_10

Firmansyah, S., J.L. Gaol, \& S.B. Susilo. 2019. Perbandingan klasifikasi SVM dan Decision Tree untuk pemetaan mangrove berbasis objek menggunakan citra satelit Sentinel-2B di Gili Sulat, Lombok Timur. $J$. Pengelolaan Sumber Daya Alam dan Lingkungan, 9(3): 746-757. https://doi.org/10.29244/jps1.9.3.746757 
Gilman, E.L., J. Ellison, V. Jungblut, H. van Lavieren, L. Wilson, F. Areki, G. Brighouse, J. Bungitak, E. Dus, M. Henry, et al. 2006. Adapting to Pacific Island mangrove responses to sea level rise and climate change. Clim. Res., 32: 161-176. https://doi:10.3354/cr032161

Giri, C., B. Pengra, Z. Zhu, A. Singh, \& L.L. Tieszen. 2007. Monitoring mangrove forest dynamics of the Sundarbans in Bangladesh and India using multitemporal satellite data from 1973 to 2000. Estuar. Coast. Shelf Sci., 73: 91-100.

https://doi.org/10.1016/j.ecss.2006.12 .019

Giri, C., E. Ochieng, L.L. Tieszen, Z. Zhu, A. Singh, T. Loveland, J. Masek, \& N. Duke. 2011. Status and distribution of mangrove forests of the world using earth observation satellite data. Global Ecol. Biogeogr., 20: 154-159. https://doi.org/10.1111/j.14668238.2010.00584.x

Hastiana, Y., F. Sjarkowi, D.D.A. Putranto, \& R. Ridho. 2010. Analisis perubahan kawasan mangrove berdasarkan interpretasi data spasial di Tn. Sembilang, Pantai Timur Sumatera, Banyuasin, Sumsel. Eksakta, 11(2): 53-62.

https://journal.uii.ac.id/Eksakta/article /view/2392

Hendrawan, J.L. Gaol, \& S.B. Susilo. 2018. Studi kerapatan dan perubahan tutupan mangrove menggunakan citra satelit di Pulau Sebatik Kalimantan Utara. J. Ilmu dan Teknologi Kelautan Tropis, 10(1): 99-110. https://doi.org/10.29244/jitkt.v10i1.18 595

Heumann, B.W. 2011. Satellite remote sensing of mangrove forests: recent advances and future opportunities. Progress in Physical Geography, 35(1): 87-108. https://doi.org/10.1177/03091333103 85371

Jhonnerie, R., V.P. Siregar, B. Nababan, L.B. Prasetyo, \& S. Wouthuyzen. 2014. Deteksi perubahan tutupan mangrove menggunakan citra Landsat berdasarkan klasifikasi hibrida di Sungai Kembung Pulau Bengkalis Provinsi Riau. J. Ilmu dan Teknologi Kelautan Tropis, 6(2): 491-506. https://doi.org/10.29244/jitkt.v6i2

Karyono, A., R. Pribadi, \& M. Helmi. 2013. Analisis perubahan luas mangrove berdasarkan citra satelit IKONOS tahun 2004 dan 2010 di kecamatan Mlonggo, Tahunan dan Kedung Kabupaten Jepara Jawa Tengah. J. Mar. Res., 2(3): 129-137. https://doi.org/10.14710/jmr.v2i3.314 1

Kuenzer, C., A. Bluemel, S. Gebhardt, T. vo Quoc, \& S. Dech. 2011. Remote sensing of mangrove ecosystems: A review. Remote Sens., 3: 878-928. https://doi.org/10.3390/rs3050878

Lembaga Ilmu Pengetahuan Indonesia (LIPI). 2014. Panduan monitoring status ekosistem mangrove. PT. Sarana Komunikasi Utama. Jakarta. $35 \mathrm{hlm}$.

Liu, D. \& F. Xia. 2010. Assessing objectbased classification: advantages and limitations. Remote Sens. Lett, 1(4): 187-194.

https://doi.org/10.1080/01431161003 743173

Madanguit, C.J.G., J.P.L. Onez, H.G. Tan, M.D. Villanueva, J.E. Ordaneza, R.M. Aurelio Jr., \& A.U. Novero. 2017. Application of Support Vector Machine (SVM) and Quick Unbiased Efficient Statistical Tree (QUEST) algorithms on mangrove and agricultural resource mapping using LiDAR Data Sets. Int. J. Appl. Environ. Sci., 12(10): 1821-1830. https://www.ripublication.com/ijaes1 7/ijaesv12n10_06.pdf 
Mallinis, G., I. Mitsopoulos, \& I. Chrysafi. 2018. Evaluating and comparing Sentinel 2A and Landsat-8 Operational Land Imager (OLI) spectral indices for estimating fire severity in a Mediterranean pine ecosystem of Greece. GISci. Remote Sens., 55(1): 1-18. https://doi.org/10.1080/15481603.201 7.1354803

Mazda, Y., M. Magi, H. Nanao, M. Kogo, T. Miyagi, N. Kanazawa, \& D. Kobashi. 2002. Coastal erosion due to longterm human impact on mangrove forest. Wetl. Ecol. Manag., 10: 1-9. https://doi.org/10.1023/A:101434301 7416

Myint, S.W., P. Gober, A. Brazel, S. Grossman-Clarke, \& Q. Weng. 2011. Per-pixel vs. object-based classification of urban land cover extraction using high spatial resolution imagery. Remote Sens. Environ., 115: 11451161.

https://doi.org/10.1016/j.rse.2010.12. 017

Nagelkerken, I., S.J.M. Blaber, S. Bouillon, P. Green, M. Haywood, L.G. Kirton, J.O. Meynecke, J. Pawlik, H.M. Penrose, A. Sasekumar, et al. 2008. The habitat function of mangroves for terrestrial and marine fauna: A review. Aquat. Bot., 89: 155-185.

https://doi.org/10.1016/j.aquabot.200 7.12.007

Noor, Y.R., M. Khazali, \& I.N.N. Suryadiputra. 2012. Panduan pengenalan mangrove di Indonesia. PHKA/WI-IP. Bogor. $220 \mathrm{hlm}$.

Nugroho, A.S., A.B. Witarto, \& D. Handoko. 2003. Application of support vector machine in bioinformatics. In: Proceeding Indonesia Scientific Meeting, Central Japan, Gifu, 1-11 pp. https://asnugroho.net/papers/ikcsvm.p df
Ostling, J.L., D.R. Butler, \& R.W. Dixon. 2009. The biogeomorphology of mangroves and their role in natural hazards mitigation. Geogr. Compass, 3(5): 1607-1624.

https://doi.org/10.1111/j.1749-

8198.2009.00265.x

Pujiono, E., D.A. Kwak, W.K. Lee, Sulistyanto, S.R. Kim, J.Y. Lee, S.H. Lee, T. Park, \& M.I. Kim. 2013. RGB-NDVI color composites for monitoring the change in mangrove area at the Maubesi Nature Reserve, Indonesia. Forest Sci. Technol., 9(4): 171-179.

https://doi.org/10.1080/21580103.201 3.842327

Rosmasita, V.P. Siregar \& S.B. Agus. 2018. Klasifikasi mangrove berbasis objek dan piksel menggunakan citra Sentinel-2B di Sungai Liong, Bengkalis, Provinsi Riau. J. Ilmu dan Teknologi Kelautan Tropis, 10(3): 601-615.

https://doi.org/10.29244/jitkt.v10i3.22 182

Sarkar, S.K. \& A.K. Bhattacharya. 2003. Conservation of biodiversity of the coastal resources of Sundarbans, Northeast India: an integrated approach through environmental education. Mar. Pollut. Bul., 47: 260264. https://doi.org/10.1016/S0025326X(02)00475-7

Shafri, H.Z.M. \& F.S.H. Ramie. 2009. A comparison of support vector machine and decision tree classifications using satellite data of Langkawi Island. Inf. Technol. J., 8(1): 64-70.

https://doi.org/10.3923/itj.2009.64.70

Stow, D., Y. Hamada, L. Coulter, \& Z. Anguelova. 2008. Monitoring shrubland habitat changes through object-based change identification with airborne multi-spectral imagery. Remote Sens. Environ., 112: 10511061. 
https://doi.org/10.1016/j.rse.2007.07. 011

Thampanya, U., J.E. Vermaat, S. Sinsakul, \& N. Panapitukkul. 2006. Coastal erosion and mangrove progradation of Southern Thailand. Estuar. Coast. Shelf Sci., 86(1): 75-85. https://doi.org/10.1016/j.ecss.2006.01 .011

Tzotzos, A. 2006. A support vector machine approach for object based image analysis. 2006. In: 1st International Conference on Object-based Image Analysis, OBIA, Salzburg, Austria, 45 Juli. 6 p.

https://www.isprs.org/proceedings/xx $\mathrm{xvi} / 4-$

C42/Papers/09_Automated\%20classif ication\%20Generic\%20aspects/OBIA 2006_Tzotsos.pdf
Wahidin, N., V.P. Siregar, B. Nababan, I. Jaya, \& S. Wouthuyzend. 2015. Object-based image analysis for coral reef benthic habitat mapping with several classification algorithms. Procedia Environmental Sciences, 24: 222-227. https://doi.org/10.1016/j.proenv.2015. 03.029

Zhu, G. \& D.G. Blumberg. 2002. Classification using ASTER data and SVM algorithms; The case study of Beer Sheva, Israel. Remote Sens. Environ., 80: 233-240. https://doi.org/10.1016/S00344257(01)00305-4

Received : 21 October 2019

Reviewed : 20 November 2019

Accepted : 07 March 2021 
